ANDRZEJ OSUCH, PiOTR RYBACKI, EWA OSUCH, PRZEMYSŁAW PRZYGODZIŃSKI, JULIANNA RATAJCZAK

Institute of Biosystem Engineering Poznań University of Life Sciences

\title{
ANALYSIS OF SCHEDULE AND EXECUTION OF TECHNICAL INSPECTIONS OF AGRICULTURAL TRACTORS
}

\author{
ANALIZA HARMONOGRAMU I SPOSOBU REALIZACJI \\ PRZEGLĄDÓW TECHNICZNYCH CIĄGNIKÓW ROLNICZYCH
}

\begin{abstract}
Summary
Technical servicing is an integral element in the operation system of tractors and other agricultural machines. Servicing processes include mainly operations performed within the framework of scheduled periodical technical inspections, which objective is to ensure operability of technical objects and maximum extension of their failure-free operation. The aim of this study was to collect data on the execution of technical servicing for agricultural tractors used on family farms and to determine their proper scheduling. Analyses were conducted using a questionnaire distributed among farmers from the Wielkopolskie province. This study showed that most farmers perform technical servicing of tractors on farms, thus ignoring the schedule for the execution of technical inspections specified in the vehicle manual.
\end{abstract}

Key words: servicing of machines, agricultural tractor

\section{Introduction}

Agricultural machines are technical objects, characterised by considerable variability in comparison to other machines. They need to meet numerous requirements, resulting from the unique character of agricultural production, which rhythmicality is connected with climatic and weather conditions (Osuch et al., 2015b; Rybacki and Durczak, 2011). Operation of agricultural machines comprises several processes performed by machine operators. It is composed of a set of relationships between technical objects and their users from the time of machine purchase to its sale or disposal. Operating processes include machine usage, operation and supply with materials and parts (Buchwald et al., 
Osuch, A., Rybacki, P., Osuch, E., Przygodziński, P., Ratajczak, J. (2016). Analysis of schedule and execution of technical inspections of agricultural tractors. Nauka Przyr. Technol., 10, 4, \#41. DOI: http://dx.doi.org/10.17306/ J.NPT.2016.4.41

2015; Rzeźnik, 2008). In practice technical operation of agricultural machines is referred to as technical servicing, which objective is to ensure operability of technical objects. Technical inspections are the primary processes within the technical servicing systems for agricultural tractors (Rybacki, 2009; Rybacki and Durczak, 2011, 2012; Rzeźnik, 2008; Tomczyk, 2009). Inspections of agricultural vehicles should be performed after service life periods specified by the manufacturer, while the length of guaranteed failure-free operation at properly selected consumables is defined by the number of engine hours. Tractors on farms are used with varying intensity in successive months of the year, thus making it difficult to precisely forecast demand for servicing operations of servicing stations. The number of tractors covered by warranty servicing is known; however, it is not possible to precisely specify the schedule for executed technical inspections. It is especially difficult to estimate the number of post-warranty inspections (Juściński and Piekarski, 2008, 2009; Juściński and Szczepanik, 2008). Maintenance of operability in the case of agricultural tractors is a complex process due to their unique working conditions. The primary task is to timely perform operations connected with replacement of consumables, to counter destructive processes characteristic of agricultural machines, i.e. ageing and wear (Buchwald and Staszak, 2013; Grądkowski et al., 1999; Rzeźnik, 2008). Inadequate operation of agricultural machines by delaying the execution of servicing operations and replacement of suitable consumables with substitute materials may result in an undesirable failure of the machine (Buchwald and Staszak, 2013; Jósko and Kołodziejski, 2008). In agricultural tractors servicing processes include mainly prevention operations. The most frequently executed operations are supplementation and replacement of operating fluids as well as lubrication and regulation of mechanisms, accounting for over $80 \%$ all performed servicing operations (Buchwald and Staszak, 2013; Buchwald et al., 2015). Prevention of failure and wear in machine maintenance processes is frequently inadequate. It results both from the insufficient knowledge on the principles of maintenance processes for agricultural machines and the intention to minimise the share of technical servicing costs in expenses incurred by farmers (Skrobacki and Ekielski, 2006). Users of agricultural machines frequently try to extend the periods between technical inspections, while also tending to search for substitute consumables (Buchwald and Staszak, 2013). Substitute consumables are often inadequate and frequently do not meet the specifications of agricultural machines. Farmers, willing to maximally reduce maintenance costs of their agricultural machines, particularly older or past their warranty period, often perform servicing operations themselves. It needs to be stressed that typically farmers are not experts and do not have the required specialist knowledge on machine servicing, thus they gain experience based on the trial-and-error method when executing technical servicing operations. Errors in technical servicing of agricultural machines, particularly engine-powered, may lead to accelerated wear to failure of subassemblies, which in turn may result in high costs of required damage repairs. Analyses were conducted for servicing of agricultural tractors on family farms in the Wielkopolskie province. This study may prove useful in the adaptation of servicing stations to customised requirements of individual users of engine-powered agricultural machines. Well-executed processes of technical servicing in the case of tractors and other agricultural machines facilitate their potential efficient use, which directly influences the economic results of farms. 
Osuch, A., Rybacki, P., Osuch, E., Przygodziński, P., Ratajczak, J. (2016). Analysis of schedule and execution of technical inspections of agricultural tractors. Nauka Przyr. Technol., 10, 4, \#41. DOI: http://dx.doi.org/10.17306/ J.NPT.2016.4.41

\section{Material and methods}

The aim of this study was to analyse the observation of schedules of technical inspections for agricultural tractors and to identify approaches to their execution. Analysis of the collected data made it possible to determine the current situation in servicing of agricultural machines, particularly agricultural tractors. This paper presents the developed multiple criterion questionnaire as well as a list and an analysis of results, which made it possible to formulate conclusions. The questionnaires were sent to owners of family farms in the Wielkopolskie province. The survey was conducted in 2015 in around a dozen of farms, in which farmers used a total of 31 agricultural tractors of various makes, differing in their horse power and in the length of their service life. Respondents answered questions concerning technical servicing of owned agricultural tractors - their course or the intervals between technical inspections, execution of technical servicing (authorised servicing stations, local servicing stations or on the farm), while they also specified the make and model of the tractor as well as their horse power and year of production. Based on the analysis of the results the actual condition was assessed, resulting from the observation of the technical servicing schedule.

\section{Results and discussion}

Farmers running family farms typically use tractors of two makes - Ursus and Zetor, although Massey Fergusons are also common. They are tractors, which service periods exceed 20 years. Table 1 presents all analysed agricultural tractors.

Table 1. Summary of tractors analysed

Tabela 1. Zestawienie ciągników poddanych analizie

\begin{tabular}{|c|c|c|c|c|c|c|}
\hline $\begin{array}{l}\text { No. } \\
\text { Lp. }\end{array}$ & $\begin{array}{l}\text { Make } \\
\text { Marka }\end{array}$ & $\begin{array}{l}\text { Model } \\
\text { Model }\end{array}$ & $\begin{array}{l}\text { Year of } \\
\text { production } \\
\text { Rok } \\
\text { produkcji }\end{array}$ & $\begin{array}{c}\text { Power } \\
\text { Moc } \\
(\mathrm{kW})\end{array}$ & $\begin{array}{l}\text { Frequency } \\
\text { of technical } \\
\text { inspections } \\
\text { Częstotliwość } \\
\text { przeglądów } \\
\text { technicznych }\end{array}$ & $\begin{array}{l}\text { Execution of technical } \\
\text { inspections } \\
\text { Sposób wykonywania } \\
\text { przeglądów } \\
\text { technicznych }\end{array}$ \\
\hline 1 & 2 & 3 & 4 & 5 & 6 & 7 \\
\hline 1 & Zetor & 7711 & 1990 & 53.69 & $\begin{array}{l}\text { Once a year } \\
\text { Raz w roku }\end{array}$ & $\begin{array}{l}\text { On farm } \\
\text { We własnym zakresie }\end{array}$ \\
\hline 2 & Claas & Celtis 426 & 2007 & 52.96 & $300 \mathrm{mth}$ & $\begin{array}{l}\text { On farm } \\
\text { We własnym zakresie }\end{array}$ \\
\hline 3 & Massey Ferguson & 5410 & 2012 & 55.16 & $300 \mathrm{mth}$ & $\begin{array}{l}\text { Local servicing station } \\
\text { Serwis lokalny }\end{array}$ \\
\hline 4 & Fendt & $108 \mathrm{LS}$ & 1980 & 55.16 & $250 \mathrm{mth}$ & $\begin{array}{l}\text { On farm } \\
\text { We własnym zakresie }\end{array}$ \\
\hline 5 & Zetor & 7745 & 1991 & 53.69 & $\begin{array}{l}\text { Once a year } \\
\text { Raz w roku }\end{array}$ & $\begin{array}{l}\text { Local servicing station } \\
\text { Serwis lokalny }\end{array}$ \\
\hline
\end{tabular}


Osuch, A., Rybacki, P., Osuch, E., Przygodziński, P., Ratajczak, J. (2016). Analysis of schedule and execution of technical inspections of agricultural tractors. Nauka Przyr. Technol., 10, 4, \#41. DOI: http://dx.doi.org/10.17306/ J.NPT.2016.4.41

Table 1 - cont. / Tabela 1 - cd.

\begin{tabular}{|c|c|c|c|c|c|c|}
\hline 1 & 2 & 3 & 4 & 5 & 6 & 7 \\
\hline 6 & Zetor & 7211 & 1987 & 48.54 & $\begin{array}{l}\text { Once a year } \\
\text { Raz w roku }\end{array}$ & $\begin{array}{l}\text { On farm } \\
\text { We własnym zakresie }\end{array}$ \\
\hline 7 & Fendt & 305 LS & 1983 & 45.60 & $\begin{array}{l}\text { Once a year } \\
\text { Raz w roku }\end{array}$ & $\begin{array}{l}\text { On farm } \\
\text { We własnym zakresie }\end{array}$ \\
\hline 8 & Zetor & 7011 & 1982 & 47.81 & $\begin{array}{l}\text { Once a year } \\
\text { Raz w roku }\end{array}$ & $\begin{array}{l}\text { On farm } \\
\text { We własnym zakresie }\end{array}$ \\
\hline 9 & Massey Ferguson & 6110 & 1995 & 52.22 & $350 \mathrm{mth}$ & $\begin{array}{l}\text { On farm } \\
\text { We własnym zakresie }\end{array}$ \\
\hline 10 & Kubota & M 6060 & 2014 & 48.54 & $400 \mathrm{mth}$ & $\begin{array}{l}\text { Authorised servicing } \\
\text { station } \\
\text { Serwis autoryzowany }\end{array}$ \\
\hline 11 & Massey Ferguson & 6120 & 1996 & 58.84 & $\begin{array}{l}\text { Once a year } \\
\text { Raz w roku }\end{array}$ & $\begin{array}{l}\text { On farm } \\
\text { We własnym zakresie }\end{array}$ \\
\hline 12 & Case & Puma 145 & 2015 & 107.38 & $400 \mathrm{mth}$ & $\begin{array}{l}\text { Authorised servicing } \\
\text { station } \\
\text { Serwis autoryzowany }\end{array}$ \\
\hline 13 & Zetor & 6245 & 1991 & 44.87 & $200 \mathrm{mth}$ & $\begin{array}{l}\text { On farm } \\
\text { We własnym zakresie }\end{array}$ \\
\hline 14 & Ursus & C-355 & 1972 & 33.10 & $\begin{array}{l}\text { Once in two years } \\
\text { Raz na dwa lata }\end{array}$ & $\begin{array}{l}\text { On farm } \\
\text { We własnym zakresie }\end{array}$ \\
\hline 15 & Massey Ferguson & 3050 & 1992 & 52.22 & $250 \mathrm{mth}$ & $\begin{array}{l}\text { On farm } \\
\text { We własnym zakresie }\end{array}$ \\
\hline 16 & New Holland & TD 85D & 2003 & 61.78 & $300 \mathrm{mth}$ & $\begin{array}{l}\text { On farm } \\
\text { We własnym zakresie }\end{array}$ \\
\hline 17 & Zetor & 6340 & 1996 & 53.69 & $250 \mathrm{mth}$ & $\begin{array}{l}\text { Local servicing station } \\
\text { Serwis lokalny }\end{array}$ \\
\hline 18 & Ursus & C-330 & 1975 & 22.06 & $\begin{array}{l}\text { Once a year } \\
\text { Raz w roku }\end{array}$ & $\begin{array}{l}\text { On farm } \\
\text { We własnym zakresie }\end{array}$ \\
\hline 19 & Ursus & C-360 & 1988 & 34.57 & $\begin{array}{l}\text { Once in two years } \\
\text { Raz na dwa lata }\end{array}$ & $\begin{array}{l}\text { Local servicing station } \\
\text { Serwis lokalny }\end{array}$ \\
\hline 20 & Claas & Celtis 456 & 2008 & 74.29 & $300 \mathrm{mth}$ & $\begin{array}{l}\text { On farm } \\
\text { We własnym zakresie }\end{array}$ \\
\hline 21 & Fendt & 312 & 2011 & 91.94 & $300 \mathrm{mth}$ & $\begin{array}{l}\text { Local servicing station } \\
\text { Serwis lokalny }\end{array}$ \\
\hline 22 & Ursus & C-4011 & 1968 & 33.10 & $\begin{array}{l}\text { Once a year } \\
\text { Raz w roku }\end{array}$ & $\begin{array}{l}\text { On farm } \\
\text { We własnym zakresie }\end{array}$ \\
\hline 23 & Ursus & C-330 & 1983 & 22.06 & $\begin{array}{l}\text { Once in two years } \\
\text { Raz na dwa lata }\end{array}$ & $\begin{array}{l}\text { On farm } \\
\text { We własnym zakresie }\end{array}$ \\
\hline 24 & Ursus & C-360 & 1992 & 34.57 & $\begin{array}{l}\text { Once a year } \\
\text { Raz w roku }\end{array}$ & $\begin{array}{l}\text { On farm } \\
\text { We własnym zakresie }\end{array}$ \\
\hline
\end{tabular}


Osuch, A., Rybacki, P., Osuch, E., Przygodziński, P., Ratajczak, J. (2016). Analysis of schedule and execution of technical inspections of agricultural tractors. Nauka Przyr. Technol., 10, 4, \#41. DOI: http://dx.doi.org/10.17306/ J.NPT.2016.4.41

Table 1 - cont. / Tabela $1-$ cd.

\begin{tabular}{|c|c|c|c|c|c|c|}
\hline 1 & 2 & 3 & 4 & 5 & 6 & 7 \\
\hline 25 & Massey Ferguson & 5465 & 2012 & 97.09 & $400 \mathrm{mth}$ & $\begin{array}{l}\text { Local servicing station } \\
\text { Serwis lokalny }\end{array}$ \\
\hline 26 & Ursus & C-330 & 1980 & 22.06 & $\begin{array}{l}\text { Once a year } \\
\text { Raz w roku }\end{array}$ & $\begin{array}{l}\text { On farm } \\
\text { We własnym zakresie }\end{array}$ \\
\hline 27 & Ursus & C-360 & 1983 & 38.25 & $\begin{array}{l}\text { Once in two years } \\
\text { Raz na dwa lata }\end{array}$ & $\begin{array}{l}\text { On farm } \\
\text { We własnym zakresie }\end{array}$ \\
\hline 28 & New Holland & TS $100 \mathrm{~A}$ & 2005 & 74.29 & $350 \mathrm{mth}$ & $\begin{array}{l}\text { On farm } \\
\text { We własnym zakresie }\end{array}$ \\
\hline 29 & Ursus & C-330 & 1985 & 22.06 & $\begin{array}{l}\text { Once a year } \\
\text { Raz w roku }\end{array}$ & $\begin{array}{l}\text { On farm } \\
\text { We własnym zakresie }\end{array}$ \\
\hline 30 & Ursus & $\mathrm{C}-360$ & 1980 & 38.25 & $\begin{array}{l}\text { Once a year } \\
\text { Raz w roku }\end{array}$ & $\begin{array}{l}\text { On farm } \\
\text { We własnym zakresie }\end{array}$ \\
\hline 31 & John Deere & $6105 \mathrm{M}$ & 2014 & 77.23 & $400 \mathrm{mth}$ & $\begin{array}{l}\text { Authorised servicing } \\
\text { station } \\
\text { Serwis autoryzowany }\end{array}$ \\
\hline
\end{tabular}

The execution of technical inspections on family farms is typically dependent on the age of tractors. During the warranty period guaranteed by the manufacturer (or the warranty extended by the dealer) agricultural machines are serviced in authorised servicing stations. The length of the warranty period depends on the tractor manufacturer and ranges from 12 to 60 months. The average age of analysed tractors is over 22 years, which greatly exceeds the average age of tractors in Poland, which according to Durczak (2011) and Osuch et al. (2015a) is over 17 years. Tractors varied in terms of the horse power generated by the engine, with the weakest tractor of $22 \mathrm{~kW}$ horse power and the strongest of $107 \mathrm{~kW}$. The mean horse power of tractors was slightly below 52 $\mathrm{kW}$. Analyses showed that farmers do not observe the technical inspection schedules for agricultural tractors, specified in the manual based on the number of running engine hours or the maximum operating period (unless the manual specifies otherwise, 1-year intervals or 300 running engine hours are assumed between replacement of consumables, whichever comes first). As it was shown in Figure 1, over 50\% respondents declared that technical inspections are performed in 1- or 2-year intervals, regardless of the number of machine hours.

In the course of this study farmers declared three methods of technical inspection execution, i.e. the authorised servicing station, a local servicing station or by themselves on the farm. Farmers use authorised servicing stations only for tractors covered by the warranty, while they use local servicing stations typically for tractors aged max. 5 years, with some exceptions to that rule (e.g. Ursus C-360 produced in 1988). Respondents declared that they perform over $70 \%$ technical inspections themselves and that it in order to minimise costs connected with machine operation. Detailed data are given in Figure 2. The above statement indicates that farms in Poland do not have adequate financial resources, which is confirmed by Skrobacki and Ekielski (2006), Buchwald and Staszak (2013) as well as Osuch et al. (2015a). 
Osuch, A., Rybacki, P., Osuch, E., Przygodziński, P., Ratajczak, J. (2016). Analysis of schedule and execution of technical inspections of agricultural tractors. Nauka Przyr. Technol., 10, 4, \#41. DOI: http://dx.doi.org/10.17306/ J.NPT.2016.4.41
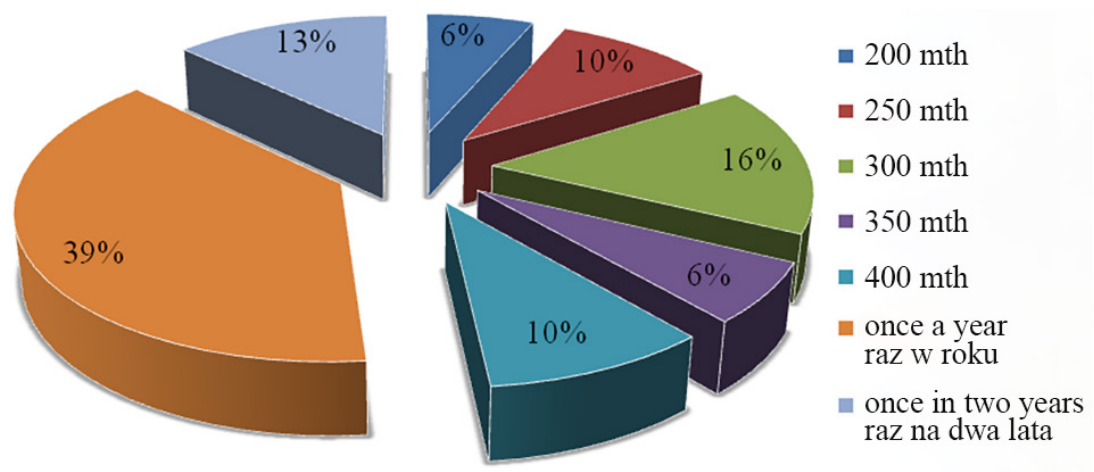

Fig. 1. Schedule for executed technical inspections Rys. 1. Realizacja harmonogramu przeglądów technicznych

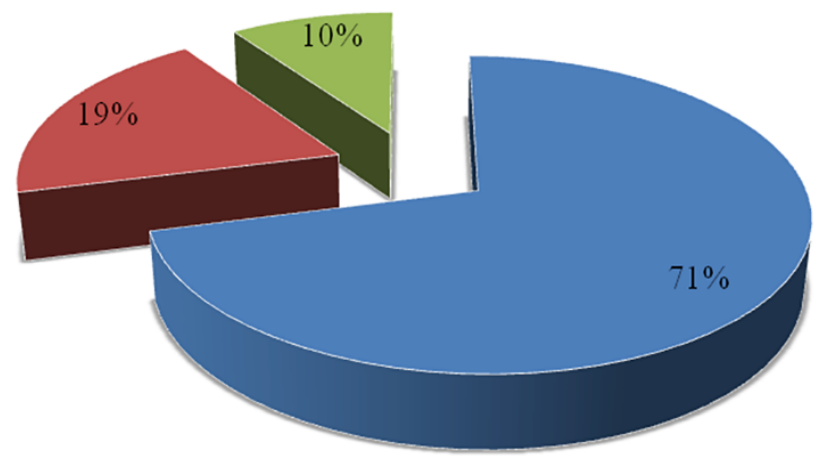
- on farm we własnym zakresie
- local servicing station serwis lokalny
a authorised servicing station serwis autoryzowany

Fig. 2. Execution of technical inspections Rys. 2. Sposoby realizacji przeglądów technicznych

\section{Conclusions}

1. After the expiry of service periods covered by the warranty of agricultural tractors farmers perform technical inspections themselves. This obviously results from limited profitability of farms; however, inadequate knowledge on machine servicing may frequently contribute to numerous errors made during technical servicing, as a consequence potentially leading to accelerated wear of subassemblies or wear to failure.

2. Farmers frequently ignore the technical servicing schedule specified in the manuals of agricultural tractors, performing inspections at extended intervals, which may result in excessive wear of subassemblies and lead to wear to failure of the machine.

3. Farms in Poland are underfinanced, as indicated by the age of used tractors. 
Osuch, A., Rybacki, P., Osuch, E., Przygodziński, P., Ratajczak, J. (2016). Analysis of schedule and execution of technical inspections of agricultural tractors. Nauka Przyr. Technol., 10, 4, \#41. DOI: http://dx.doi.org/10.17306/ J.NPT.2016.4.41

\section{References}

Buchwald, T., Rzeźnik, Cz., Staszak, Ż., Osuch, A. (2015). Sposoby zagospodarowania zużytych olejów eksploatacyjnych w zakładach serwisowych ciągników rolniczych. Nauka Przyr. Technol., 9, 4, \#53. DOI: 10.17306/J.NPT.2015.4.53

Buchwald, T., Staszak, Ż. (2013). Analiza realizacji przeglądów technicznych ciągników rolniczych. Inż. Roln., 146, 3, 47-55.

Durczak, K. (2011). System oceny jakości maszyn rolniczych. Rozpr. Nauk. UP Pozn., 418.

Grądkowski, M., Rogoś, E., Siwieć, E., Urbański, A. (1999). Oksydacyjne starzenie oleju sprężarkowego. Probl. Eksploat., 4, 75-90.

Jósko, M., Kołodziejski, D. (2008). Wybrane problemy eksploatacyjne pojazdów i maszyn rolniczych w zakresie ich serwisowania. J. Res. Appl. Agric. Eng., 53, 2, 5-7.

Juściński, S., Piekarski, W. (2008). Analiza statystyczna obsługi serwisowej ciągników rolniczych w aspekcie odległości od siedziby firmy. Inż. Roln., 100, 2, 57-65.

Juściński, S., Piekarski, W. (2009). Rozkład zapotrzebowania na przeglądy serwisowe ciągników rolniczych w aspekcie terminów agrotechnicznych. Inż. Roln., 117, 8, 31-38.

Juściński, S., Szczepanik, M. (2008). Przeglądy gwarancyjne ciągników rolniczych jako element logistyki dystrybucji. Eksploat. Niezawodn., 38, 2, 45-52.

Osuch, A., Rybacki, P., Buchwald, T., Staszak, Ż., Ratajczak, J. (2015a). Analiza stanu wyposażenia gospodarstw rolnych w ciągniki rolnicze. Problemy eksploatacji maszyn i ciągników rolniczych. In: M. Lipiński, J. Przybył (eds.), Aktualne problemy inżynierii biosystemów (pp. 91-101). Poznań: Wyd. UP.

Osuch, A., Rybacki, P., Kot, W. (2015b). Analiza stanu wyposażenia gospodarstw rolnych w kombajny do zbioru zbóż. Tech. Roln. Ogrodn. Leśn., 3, 10-12.

Rybacki, P. (2009). Nanotechnologia w obsłudze technicznej maszyn rolniczych. Tech. Roln. Ogrodn. Leśn., 5, 11-13.

Rybacki, P., Durczak, K. (2011). Ocena jakości serwisu technicznego maszyn rolniczych. Inż. Roln., 134, 9, 201-206.

Rybacki, P., Durczak, K. (2012). Hierarchizacja kryteriów oceny jakości procesów serwisowania maszyn rolniczych metodą porównywania. Inż. Roln., 136, 2, 299-306.

Rzeźnik, Cz. (2008). Podstawy obsługi technicznej maszyn rolniczych. Poznań: Wyd. AR.

Skrobacki, A., Ekielski, A. (2006). Pojazdy i ciągniki rolnicze. Warszawa: Wieś Jutra.

Tomczyk, W. (2009). Obsługi techniczne w procesie odnowy i utrzymania maszyn i urządzeń rolniczych. Inż. Roln., 115, 6, 301-307.

\section{ANALIZA HARMONOGRAMU I SPOSOBU REALIZACJI PRZEGLĄDÓW TECHNICZNYCH CIĄGNIKÓW ROLNICZYCH}

\section{Streszczenie}

Obsługa techniczna jest integralną częścią systemu eksploatacji ciągników i innych maszyn rolniczych. Procesy serwisowania obejmują głównie operacje wchodzące w skład planowanych okresowych przeglądów technicznych, których celem jest zapewnienie obiektom technicznym zdatności do użytkowania i maksymalnego wydłużenia okresu ich bezawaryjnej pracy. Celem badań było uzyskanie informacji dotyczącej sposobów wykonywania obsługi technicznej ciągników rolniczych eksploatowanych w rodzinnych gospodarstwach rolnych oraz określenie prawidłowego przestrzegania ich harmonogramu. Badania wykonano $\mathrm{z}$ wykorzystaniem kwestionariusza 
Osuch, A., Rybacki, P., Osuch, E., Przygodziński, P., Ratajczak, J. (2016). Analysis of schedule and execution of technical inspections of agricultural tractors. Nauka Przyr. Technol., 10, 4, \#41. DOI: http://dx.doi.org/10.17306/ J.NPT.2016.4.41

ankietowego wśród rolników z województwa wielkopolskiego. Jak wynika z tych badań, większość rolników dokonuje obsługi technicznej ciągników we własnym zakresie, ignorując przy tym harmonogram wykonywania przeglądów technicznych określony w instrukcji obsługi pojazdu.

Słowa kluczowe: serwisowanie maszyn, ciągnik rolniczy

Corresponding address - Adres do korespondencji:

Andrzej Osuch, Instytut Inżynierii Biosystemów, Uniwersytet Przyrodniczy w Poznaniu, ul. Wojska Polskiego 50,60-627 Poznań, Poland, e-mail: andrzej.osuch@up.poznan.pl

Accepted for publication - Zaakceptowano do opublikowania:

18.10.2016

For citation - Do cytowania:

Osuch, A., Rybacki, P., Osuch, E., Przygodziński, P., Ratajczak, J. (2016). Analysis of schedule and execution of technical inspections of agricultural tractors. Nauka Przyr. Technol., 10, 4, \#41. DOI: http://dx.doi.org/10.17306/J.NPT.2016.4.41 